Journal of Applied Pharmaceutical Science Vol. 6 (01), pp. 035-041, January, 2016

Available online at http://www.japsonline.com

DOI: $10.7324 / \mathrm{JAPS} .2016 .600106$

ISSN 2231-3354 (cc)) BY-NC-SA

\title{
Identification and characterization of Lactobacillus bacterial genera most prevalent used to improve silage digestibility of important forage species for livestock sector
}

\author{
Fierro Roberto ${ }^{1,2^{*}}$, Chamorro Diana ${ }^{1}$, Pazmiño Julio ${ }^{1}$, Darwin Rueda ${ }^{1}$, Zúñiga Johana ${ }^{1}$, Ríos Diego ${ }^{1}$, Bangeppagari \\ Manjunatha ${ }^{1}$, Muchakayala Ravi $^{3}$, Mariadoss Selvanayagam ${ }^{4,5}$ \\ ${ }^{1}$ Department of Life Sciences, Universidad de las Fuerzas Armadas-ESPE, Sangolquí- POBOX: 171-5-231B, Quito, Ecuador, South América. ${ }^{2}$ Faculty of \\ Prometeo Project, SENESCYT, Quito, Ecuador. ${ }^{3}$ Shenzhen Key Laboratory of Advanced Materials, Department of Materials Science and Engineering, \\ Shenzhen Graduate School, Harbin Institute of Technology, Shenzhen - 518055, China. ${ }^{4}$ Department of Environmental Engineering, Universidad Estatal \\ Amazonica, Puyo, Ecuador. ${ }^{5}$ Loyola - ICAM College of Engineering and Technology (LICET), Loyola campus, Chennai-600034, India.
}

\section{ARTICLE INFO}

Article history:

Received on: 28/10/2015

Revised on: 15/11/2015

Accepted on: 07/12/2015

Available online: 26/01/2016

Key words:

Microsilage, Lactobacillus,

Pediococcus, Nutritional

parameters, In vitro

digestibility.

\begin{abstract}
The objective of this study is to isolate and characterize lactic acid bacteria and their effect as a microbial inoculants in silage digestibility of Lolium perenne -Trifolium pratense (Rye grass - Red clover) (RG-RC), Avena sativa - Vicia sativa (Oat-Vetch) (O-V) and Corn Stover Zea mays (Corn) (C). The lactic acid bacteria (LAB) isolated from three mixtures were identified at 40 day of evolution of micro silages. Morphological, physiological, biochemical and molecular techniques were used to characterize the isolates lactic acid bacteria. The following species were identified from the mixture namely Lactobacillus buchneri, Lactobacillus plantarum, Lactobacillus brevis and Pediococcus acidilactici. 54 micro silages with each feed material were produced, 27 micro silos were inoculated with bacteria's and the rest was used as a control. The nutritional value of protein, ether extract (EE), ash, energy, neutral detergent fiber (NDF), acid detergent fiber (ADF) at 20, 30 and 40 days of ensilage was compared. The percentage of each in vitro digestibility of treatments performed on day 40 was obtained that corresponded best A-V and RG-TR inoculated with bacteria as they were $35 \%$ and $41 \%$ more digestible than the control treatments appropriate, concluding that the inoculation of lactic acid bacteria facilitated improved digestibility of silage obtaining good nutritional quality, with optimal values. These results will enable future research on the relationship between LAB species and silage fermentation quality. Use of lactic acid bacteria is recommended as an additive to improve the nutritional quality of food animals as alternative in times of scarcity of fodder or as a supplement to improve the nutritional status of livestock herd.
\end{abstract}

\section{INTRODUCTION}

Silage is a preservation technique, lactic-acidic fermentation based-on process, which can be carried out in a silo that meets the wet medium and anaerobic conditions to maintain the nutritional properties of the green fodder during the fermentation and the storage phases (Favre, 2012). Natural populations of Lactic Acid Bacteria (LAB) are responsible for conserving several cultures, such as silage. The silage process consists of the conversion of Water Soluble Carbohydrates (WSC) into organic acids (lactic acid mainly), which are capable of lowering the fodder $\mathrm{pH}$, and therefore, preserve it (Guerrero, 2013). The ensiling system enables farmers to use their facilities

\footnotetext{
* Corresponding Author

Department of Life Sciences, Universidad de las Fuerzas ArmadasESPE, Sangolquí- POBOX: 171-5-231B, Quito, Ecuador, South América.Email: cu_pri@hotmail.com
}

in a more appropriate way. By suppressing the need to deforest or to purchase more land to build new cattle corrals or paddocks, the silage technique can be implemented whenever the farmers get to experience a fodder shortage period. Consequently, a nutrientrecycling process will begin, and cattle housing management process will improve (Vieyra 2006). Additionally, this legumegrass preserving process, which provides farmers with some cutting time flexibility (Lara 2011), might also work as a daily cattle supplement that enhances the balanced rations and mineral supplementation action. Farm animal's needs mineral supplements often are required to meet their nutritional needs continuously. Additionally, several weather conditions like floods, droughts, volcanic activity, and deforestation might also lead to food shortage. As a result, an economizing supplementation alternative, such as using digestibility bacterial boosters for fodder, is required. Silage quality depends on how much crude protein, ash, energy, crude fat, additives and ethereal fraction will be handled. 
Additional parameters, such as: Water Soluble Carbohydrate quality, temperature below $40^{\circ} \mathrm{C}, \mathrm{pH} 4.2$, Homofermentative (Lactic Acid Only producer) and Heterofermentative (Lactic acid, Acetic Acid producer) bacteria content and humidity level around $60-70 \%$ affect the final silage quality (Gutiérrez 2009, Contreras 2009).

Heterofermentative microbacterial inoculants purpose is to improve the aerobic stability of silage by decreasing the yeast levels. The most common bacterial inoculant in stock is the Homofermentative Lactic Acid Producers (Filya 2003). These bacteria, whose main purpose is preserving the silage properties as near to the original green condition as possible, is capable of fulfilling several tasks, such as: reducing ammonia formation and proteolysis, keeping dry matter losses under 2-3\%, and enhancing the dry matter digestibility and production of lactic acid (Muck and Kung, 1997). Both Homofermentative and Heterofermentative Lactic Acid Producers work as $\mathrm{pH}$ level-lowers and latter aerobic stability controllers respectively. However, few lab studies involving both Lactic Acid Producers simultaneously have been conducted (Pahlow et al, 2003).

The main purposes of this current research project is to identify and typify the dominating bacterial genuses, which are bound to enhance the digestibility of livestock-relevant plants grown for fodder; and to determine the nitrogen percentage of invitro-microsilaged fodder.

\section{MATERIALS AND METHODS}

\section{Preparation of silages}

The whole crops were collected from a farm in Instituto Nacional de Investigaciones Agropecuarias (INIAP) in Pichincha Province. Silages were prepared using a small scale, a forage mixture divided into three treatments with: Lolium perenneTrifolium pratense (RG-TR), Avena sativa-Vicia sativa (A-V) and Zea mays (RM), approximately $3 \mathrm{~kg}$ of mixture forage material (30\% legume and $70 \%$ grass) chopped into about 1-3 cm length and packed into PVC tubes of $50 \mathrm{~cm}$ of large. The tubes were filled with a solution of water, molasses and urea in proportions of $10 \%, 5 \%$ and $0.1 \%$ respectively, according to the weight of micro silages. 9 micro silos was performed, three for each vegetable mix. The micro silos were stored in a room at ambient temperature (Fig. 1).

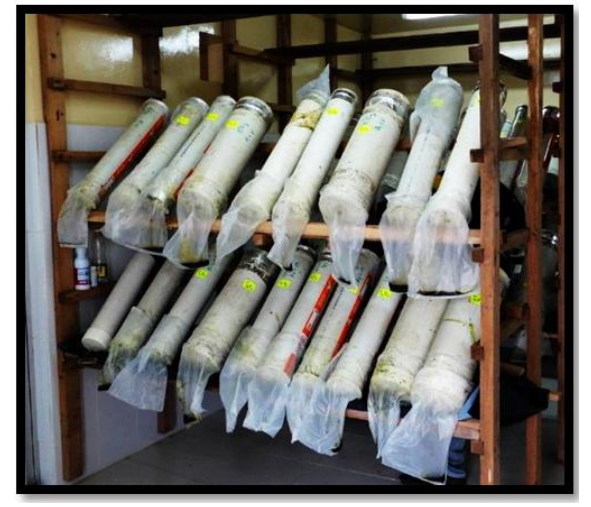

Fig. 1: Micro silos with air valves and hoses infusion.
Silage samples were collected after 45 days during the ensiling process. The samples $(10 \mathrm{~g})$ were blended with $90 \mathrm{ml}$ of sterilized water and serially diluted from $10^{-1}$ to $10^{-3}$ in sterilized water. The dilution was cultivated on Man Ragusa and Sharpe (MRS Neogen) agar (1.0\% peptone, $0.8 \%$ egg extract, $0.4 \%$ yeast extract, $2.0 \%$ glucose, $0.5 \%$ sodium acetate trihydrate, $0.1 \%$ polysorbate 80 (also known as Tween 80), 0.2\% dipotassium hydrogen phosphate, $0.2 \%$ triammonium citrate, $0.02 \%$ magnesium sulfate heptahydrate, $0.005 \%$ manganese sulfate tetrahydrate, $1.0 \%$ agar, $\mathrm{pH}$ adjusted to 6.2 at $25^{\circ} \mathrm{C}$ ) and incubated at $37^{\circ} \mathrm{C}$ for $72 \mathrm{~h}$ under anaerobic conditions. The colonies were selected according to the morphology and each colony was isolated and purified twice by streaking on MRS agar plates. Pure cultures were grown on MRS agar at $30^{\circ} \mathrm{C}$ for $24 \mathrm{~h}$, and then the purified strains were stored at $-90^{\circ} \mathrm{C}$ in glycerol solution at $15 \%$, for conservation.

\section{Isolation and Identification of Dominating Bacteria Phase}

The selection of colonies was randomly isolated from the plate containing between 35 and 300 colonies. Four dominant bacterial strains were isolated: R50, V74, M45, and T66. The identification of strains was performed after $24 \mathrm{~h}$ of incubation on MRS agar. The cultures were identified based on cell morphology, Gram stain, biochemical and physiological characteristics. Catalase and oxidase activity was determined according to Benson, 2001. Starch hydrolysis was done about describing Cheeptham, 2012. Carbohydrate fermentation tested were: Glucose, Fructose, Lactose, Galactose, Sorbitol, Maltose, Rumors, Mannitol, Sucrose and Raffinose. The tubes were added with 3 droops of sterile liquid paraffin before inoculation in order to ensure anaerobic conditions.

The growth at different temperatures was observed in MRS broth after incubation at 15,35 and $45^{\circ} \mathrm{C}$. Growth of cultures at $\mathrm{pH} 4.0,6.0,8.0$ was determinate in MRS broth after incubation at $30^{\circ} \mathrm{C}$ for 5 days.

The $16 \mathrm{~S}$ ribosomal RNA gene sequence was amplified by polymerase chain reaction from chromosomal DNA, performed in a PCR Thermal Cycler (Techne FTC41H2D, UK). The sequences of the PCR products were determined with the universal primers 27F (5'-AGAGTTTGATCMTGGCTCAG-3') and 1492R (5'-TACGGYTACCTTGTTACGA-3'). An automatic sequencer (Applied Byosistem, model No 3730XL) was used to obtain the $16 \mathrm{~S}$ rDNA sequence, $1650 \mathrm{pb}$. Alignment of the different $16 \mathrm{~S}$ rDNA sequences from Gen Bank data library using the BLAST program was performed using CLUSTALW software program (Hitachi Software Engineering Co., Tokyo, Japan).

\section{Bacterial propagation for experimental phase}

In order to make up a microbial consortium, the R50, V74, M45 and T66 strains were selected as additive at $6 \times 10^{8} \mathrm{CFU} /$ $\mathrm{g}$ of vegetal matter (Cabeza 2013). In that sense, after the identification and isolation phases were conducted, a bacterial mass propagation phase was carried out on a cultivation peptone broth (which consisted of 5 grams of dextrose, 5 grams of peptone, 
and 1 gram of $\mathrm{NaCl}$ per liter of distilled water). Bacterial concentration was subsequently determined by utilizing a Thermo Genesis, USA spectrophotometer that employed the McFarland Standards to reach a $6 \times 10^{8} \mathrm{CFU} / \mathrm{ml}$ concentration at $560 \mathrm{~nm}$.

\section{Experimental design}

According to the net weight of each ensiled fodder, 54 polyvinyl-chloride micro silos were built to contain 6 kilograms of each vegetal mixture along with a molasses $(5 \%)$, urea $(0.1 \%)$ and water $(10 \%)$ dilution. On the other hand, the micro silos containing the microbial consortium had no water in the dilution, but the $6 \times 10^{8} \mathrm{CFU} / \mathrm{ml}$ cultivation peptone broths replaced the water concentration. The micro silos consisted of a diameter of 4 inches and a 60-centimeter length.

Experimental treatments included: control micro silage (without bacteria), RG-TR + microbial consortium, RG-TR without microbial consortium; A-V + microbial consortium, A-V without microbial consortium; RM + consortium, RM without consortium.

Temperature and $\mathrm{pH}$ levels of the micro silos were measured after the loading and sealing stages were conducted.

\section{Compositional Analysis}

20, 30 and 40 days after the fermentation process took place, the micro silos RG-TR with bacteria, RG-TR without bacteria; A-V with bacteria, A-V without bacteria; RM with bacteria, RM without bacteria were harvested. The harvesting phase consisted of isolating the vegetal mixture found in the middle of the micro silo, and discarding the dilution found in the highest and lowest parts of the container.

Subsequently, an organoleptic test was conducted in order to value odor, color, texture, and fungi presence parameters, along with ethereal portion, crude protein, ash, $\mathrm{pH}$, temperature and energy levels using a 300-gram sample of ensiled matter.

\section{Digestibility tests}

In vitro digestibility tests were conducted for the dried samples of each treatment. By following the methods described by Galyean (1996). The dry matter disappearance was determined. Afterwards, vegetal substrates had to be weighed $(250 \pm 1 \mathrm{mg})$ and then placed on 60-milliliter syringes, with artificial saliva $(25 \mathrm{ml})$ and ruminal liquid, which was obtained from the annulated cows (3:1 relation).

Figures 2 and 3 to avoiding any gas leak, the syringes were sealed, and finally incubated at $39{ }^{\circ} \mathrm{C}$ for 24 hours. Following the method that Quinn et al., (2010) described, the gas production levels were measured and calculated. However, ruminal liquid, along with artificial saliva, was employed for the control treatment. Digestibility testing was done in triplicates for each treatment on each evaluation date.

Once the incubation period ended, the resulting treatments were filtered, for which CFP41 Quantitative Cellulose Filter Paper (125-millimeter diameter) was used. Finally, the liquid portion of the vegetal samples was dry in oven at $60^{\circ} \mathrm{C}$ for 24 - hours so that the $\mathrm{g} 4 \mathrm{gb}$ net weight of the digested dry matter can be measured.
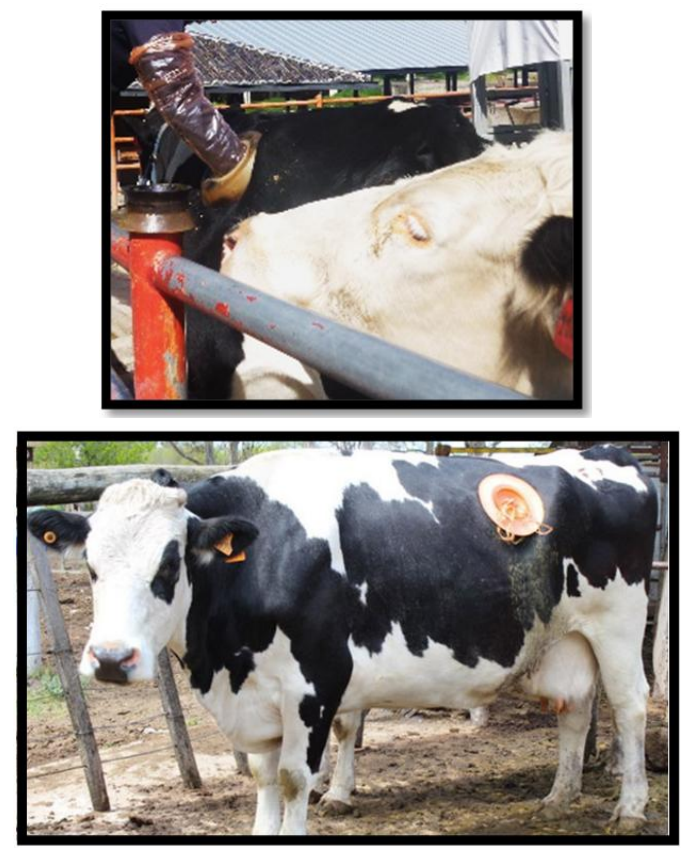

Fig. 2: Ruminal liquid obtained from cannulated cows.

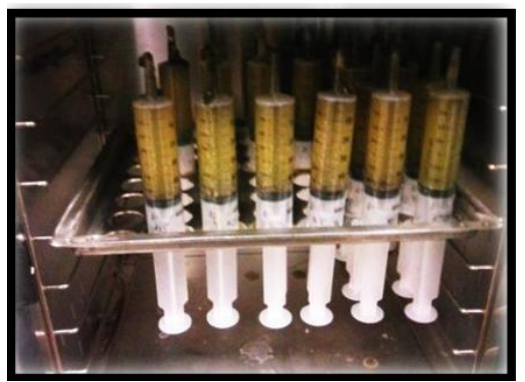

Fig. 3: Syringes with artificial saliva $(25 \mathrm{ml})$ and ruminal liquid.

\section{RESULTS AND DISCUSSION}

The dominating bacterial strains: R50, V74, M45, and T66 were isolated from micro silos RG-TR, A-V, ZM. The isolates turned out to be mostly homofermentative and heterfermentative lactic acid producers. Most of them managed to grow at 4, 6 and 8 $\mathrm{pH}$ levels, at 15 and $35^{\circ} \mathrm{C}$. The Lactobacilli isolates (R50, V74, and M45) showed rod-shaped, Gram-positive; catalase-andoxidase-negative features, while the Pediococcus sp. isolate (T66) was a round-coccus-shaped, positive-gram bacteria. Additionally, apart from being a Homofermentative producer, the Pediococcus isolate was unable to grow at an $8 \mathrm{pH}$-level. The four identified groups presented different carbohydrate fermentation levels. Some other specified physiology and biochemical characteristics are displayed in Table 1.

By means of the polymerase chain reaction technology, the dominating-strain identification was carried out. The identified strains, which turned out to be Lactobacillus, presented a 1650 bases pairs (pb) amplicon, just as the typical Gram positive coccus bacterial strain. The phenotypical and genotipical characterization 
results proved that the R50 strain turned to be Lactobacillus buchneri, the V74 strain matches to be Lactobacillus plantarum, the M45 strain was identified as Lactobacillus brevis, and the T36 strain was a Prdiococcus acidilacticci recognized match.

Lactic-acid-producing bacteria presence is necessary for the ensiling process to take place (Contreras et al, 2009), for they are able to low $\mathrm{pH}$ levels in shorter periods of time. That way, vegetal tissue transpiration can be decreased so that yeast, along with other microorganism, is inhibited and adequate anaerobical stability is achieved.

Table 1: Physiological and biochemical features of isolated strains from silages.

\begin{tabular}{|c|c|c|c|c|}
\hline Feature & $\begin{array}{c}\text { Strain } \\
\text { R50 }\end{array}$ & $\begin{array}{c}\text { Strain } \\
\text { V74 }\end{array}$ & $\begin{array}{c}\text { Strain } \\
\text { M45 }\end{array}$ & $\begin{array}{c}\text { Strain } \\
\text { T36 }\end{array}$ \\
\hline Shape & Rods & Rods & Rods & Cocci \\
\hline Gram Stain & + & + & + & + \\
\hline Catalase & - & - & - & - \\
\hline Oxidase & - & - & - & - \\
\hline $\mathrm{CO}_{2}$ from glucose & + & + & + & - \\
\hline Histamine & + & - & - & - \\
\hline Tiramine & - & + & + & - \\
\hline Phenylalanine & - & - & + & - \\
\hline Lactic acid & + & + & + & + \\
\hline Acetic acid & + & + & + & - \\
\hline \multicolumn{5}{|l|}{ Growth at $\left({ }^{\circ} \mathrm{C}\right)$ : } \\
\hline 15 & + & + & + & + \\
\hline 35 & + & + & + & + \\
\hline 45 & - & + & - & + \\
\hline \multicolumn{5}{|l|}{ Growth at pH level: } \\
\hline 4.0 & + & + & + & + \\
\hline 6.0 & + & + & + & + \\
\hline 8.0 & + & + & + & - \\
\hline Starch & - & - & - & \\
\hline Glucose & + & + & + & + \\
\hline Fructose & + & + & + & + \\
\hline Lactose & + & + & + & + \\
\hline Galactose & + & + & + & + \\
\hline Sorbitol & - & + & + & - \\
\hline Maltose & + & + & + & + \\
\hline Ramnose & - & - & - & + \\
\hline Mannitol & - & + & + & - \\
\hline Sucrose & + & + & + & - \\
\hline Raffinose & - & + & - & - \\
\hline Pre-identification & $\begin{array}{c}\text { Lactobacil } \\
\text { lus } \\
\text { buchneri }\end{array}$ & $\begin{array}{c}\text { Lactobacil } \\
\text { lus } \\
\text { plantarum }\end{array}$ & $\begin{array}{l}\text { Lactobacil } \\
\text { lus brevis }\end{array}$ & $\begin{array}{l}\text { Pediacocc } \\
\quad \text { us sp. }\end{array}$ \\
\hline
\end{tabular}

The three micro silos holding bacteria within showed similar pH levels to those described by Cobos (2012) and did not surpassed those described by Elferink, (2001). On the other hand, the non-bacterial treatments experienced more variability. Particularly, the microbial consortium was determined to have had a positive influence on drastically lowering the $\mathrm{pH}$ level. This is due to the action of Heterofermentative bacteria, which releases high quantities of lactic acid, acetic acid, lactic acid and butyric acid (vegetal acidifiers) (Contreras et al., 2009).

Table 2 shows the temperature variations of each treatment. It can be acknowledged that bacterial treatments experienced slightly higher temperatures than non-bacterial treatments. This variation lies in the metabolic cycle of lactic acid bacteria, which implies that bacterial growth leads to increasing the micro silo temperature. The effect that Heterofermentative bacteria have can be perceived after the first twenty days (stable temperature period). After this period, the Homofermentative bacterial populations decrease, and let the Heterofermentative bacterial population develop, which causes a temperature drop. After 10 days for Heterofermentative stabilization, to take place, the temperature finally becomes stable as well.

According to Gutierrez (2009), the temperature within the micro silos must never go above $40^{\circ} \mathrm{C}$. This research project also reaffirms that the sealing phase was successfully conducted within that temperature range.

\section{Component analysis}

\section{Proteins Analysis}

After 20, 30 and 40 days of ensiling, three tubes per treatment were opened to analyze the fermentation quality. The results are shown in Table 3. The analysis of the chemical composition showed that, in contrast to the non-bacterial treatments, the protein contents for RG-TR + consortium, A-V + consortium and RM + consortium micro silages exhibited were higher.

Nevertheless, a low quantity of proteins was shown by the RM treatment. This might have occurred due to the fact that this particular ensiled Stover had a low-temperature and a lowensiling quality background for coming from a seed-purpose corn field. Fuentes (2001), who utilized corn for human-consumption, known to have a high ensiling quality background.

Table 2: Temperature and $\mathrm{pH}$ and levels measurements.

\begin{tabular}{|c|c|c|c|c|c|c|c|c|}
\hline \multirow[t]{2}{*}{ Treatment } & \multicolumn{3}{|c|}{ pH } & & \multicolumn{4}{|c|}{ Temperature $\left({ }^{\circ} \mathrm{C}\right)$} \\
\hline & O day & 20 day & 30 day & 40 day & 0 day & 20 day & 30 day & 40 day \\
\hline RG-TR + consortium & 6.1 & 4.2 & 3.2 & 3.8 & 18 & 15.2 & 14.9 & 15 \\
\hline RG-TR without consortium & 6.2 & 4.9 & 4 & 3.7 & 17 & 14.5 & 14.8 & 14.3 \\
\hline $\mathrm{A}-\mathrm{V}+$ consortium & 6.1 & 4.1 & 3.5 & 4.1 & 19 & 15 & 15.3 & 15.5 \\
\hline A-V without consortium & 6.1 & 4.7 & 3.9 & 4.5 & 18 & 14 & 14 & 14.3 \\
\hline $\mathrm{RM}+$ consortium & 6 & 4.0 & 3.9 & 4.2 & 18 & 14 & 15 & 15.2 \\
\hline RM without consortium & 6.1 & 4.9 & 4.6 & 4.8 & 17 & 13.6 & 15.3 & 15.5 \\
\hline
\end{tabular}


Table 3: Component analysis of micro silos with consortium and without consortium at 20, 30 and 40 days for ensiling.

\begin{tabular}{|c|c|c|c|c|c|c|c|c|c|c|c|c|}
\hline \multirow[t]{2}{*}{ Treatment } & \multicolumn{3}{|c|}{ Proteins (\%) } & \multicolumn{3}{|c|}{ Etherealportion (\%) } & \multicolumn{3}{|c|}{$\operatorname{Ash}(\%)$} & \multicolumn{3}{|c|}{ Energy (kcal/100g) } \\
\hline & day 20 & day 30 & day 40 & day 20 & day 30 & day 40 & day 20 & day 30 & day 40 & day 20 & day 30 & day 40 \\
\hline RG-TR + consortium & 13.7 & 14.9 & 14.6 & 2.85 & 2.84 & 2.82 & 11.9 & 13.3 & 12.4 & 294.3 & 285.4 & 290.7 \\
\hline RG-TR withoutconsortium & 13 & 14 & 13.9 & 2.80 & 2.70 & 2.60 & 12.2 & 13.3 & 12.2 & 291.3 & 290.7 & 288.3 \\
\hline $\mathrm{A}-\mathrm{V}+$ consortium & 10.4 & 10.7 & 11 & 2.18 & 2.13 & 2.3 & 8.7 & 9.9 & 11.9 & 281.2 & 273.5 & 271.6 \\
\hline A-V withoutconsortium & 10.1 & 11 & 10.5 & 2.08 & 1.98 & 1.88 & 8.7 & 9.4 & 9 & 280.3 & 272.7 & 275.1 \\
\hline $\mathrm{RM}+$ consortium & 1.2 & 1.8 & 1.7 & 0.69 & 0.84 & 0.77 & 6.2 & 6.5 & 6.2 & 249.8 & 248.3 & 244.1 \\
\hline RM withoutconsortium & 1 & 1.4 & 1.1 & 0.67 & 0.84 & 0.71 & 6.4 & 7 & 6.6 & 244.6 & 242.8 & 241.9 \\
\hline
\end{tabular}

\section{Ethereal Extract (EE) Analysis}

In RM micro silos no differences were found among the treatments inoculated with bacteria and those without bacteria. The lowest percentage of EE were presented by micro silos with the RM treatment at day $30^{\text {th }}(0.84 \%)$. In the A-V and RG-TR micro silos, which held the microbial consortium, higher percentages of EE were observed in contrast to the non-inoculated micro silos (Table 3). The measurements shown on this research project happen to be in the range described by Flores and Rodriguez (2010), for an adequate silage process.

\section{Ash Analysis}

The higher value in ash content was observed in AV treatment + consortium and RG-TR + consortium micro silages at $30^{\text {th }}$ days of ensiling (Table 3 ). The values obtained in this study have a close relation with those established by Calsamiglia et al., (2004) which determined $12.8 \%$ as top quality silage value. The lowest values were presented by RM micro silage at 20 and 40 days of fermentation.

\section{Energy levels Analysis}

Non-bacterial micro silos showed lower values unlike the treatments that held the bacteria consortium within (Table 3). This is due to the fact that a greater bacterial action on the cell wall of stubble was experienced in the bacterial treatments, leaving energy reserves exposed and available for fermentation. On the other hand, the results of energy in RM micro silos were lower than the micro silos inoculated with consortium.

\section{Digestibility tests}

In order to determine the digestibility levels of silage, the gas production had to be measured for this parameter is directly proportional to the digestibility. Table 4 displays gas production levels at a 24 and 48-hours period of in vitro digestibility. According to statistical analysis at $24 \mathrm{~h}$, there are significant differences between treatment $\mathrm{AV}+$ consortium $(\mathrm{Gas}$ production $=$ $162.13 \mathrm{~cm}^{3}$ ) and the A-V treatments without consortium (Gas production $\left.=105.27 \mathrm{~cm}^{3}\right) ; \mathrm{RM}+$ consortium $\left(155.24 \mathrm{~cm}^{3}\right)$ and $\mathrm{RM}$ without Consortium $\left(137.32 \mathrm{~cm}^{3}\right)$ which reaffirm that bacterial inoculation enhance the digestibility of silage. Additionally, a numerical difference can be observed in treatments (RG-TR + consortium, RG-TR without consortium). In addition, it was observed that the best treatment was AV + consortium, for it showed a higher gas production in contrast to the other treatments. Comparing gas production at $48 \mathrm{~h}$ in different forages with the presence and absence of consortium, it appeared that there are significant differences between treatments RG-TR + consortium $\left(\mathrm{PG}=155.94 \mathrm{~cm}^{3}\right)$ and treatments RG-TR without consortium (PG $=91.7 \mathrm{~cm}^{3}$ ). The bacterial consortium helps digestibility of silage material efficiently even at $48 \mathrm{~h}$.

Table 4: In vitro digestibility of dry matter in the different treatments with and without bacterial consortium.

\begin{tabular}{|c|c|c|c|}
\hline & Treatment & $\begin{array}{c}\text { Gas } \\
\text { production at } \\
\text { a 24-hour }\end{array}$ & $\begin{array}{c}\text { Gas production } \\
\text { at a } 48-\text { hour } \\
\text { period }\left(\mathrm{cm}^{3}\right)\end{array}$ \\
\hline & RM + consortium & 155.24 & 129.32 \\
\hline & RM without consortium & 13732 & 124.62 \\
\hline E & $\mathrm{A}-\mathrm{V}+$ consortium & 162.13 & 145.1 \\
\hline कृ & A-V without consortium & 105.27 & 152.83 \\
\hline E气 & RG-TR + consortium & 158.88 & 155.94 \\
\hline & RG-TR without consortium & 158.32 & 91.7 \\
\hline
\end{tabular}

Finally, by comparing the treatments inoculated with bacteria and treatment without bacteria, it was observed that the use of bacteria as microbial inoculants improve and enhance the silage, obtaining higher production of gas in the treatments inoculated with bacteria at both 24 hours treatment $(\mathrm{PG}=152.75 \mathrm{cc})$ and 48 hours $(143.59$ cc), compared to treatments without bacteria ( 24 hours, PG = $139.63 \mathrm{cc}$ ) and (48 hours, 124.72cc) as shown in Table 5. Corroborating the results obtained in investigations of Nsereko et al., 2008 and Contreras, 2009 who affirmed that the application of bacteria improve digestibility of silage.

Table 5: Average gas production levels

\begin{tabular}{ccc}
\hline Ensiling time & $\begin{array}{c}\text { Gas production with } \\
\text { consortium (cc) }\end{array}$ & $\begin{array}{c}\text { Gas production without } \\
\text { consortium }(\mathbf{c c})\end{array}$ \\
\hline $24 \mathrm{H}$ & 152.75 & 139.63 \\
$48 \mathrm{H}$ & 143.59 & 124.72 \\
\hline
\end{tabular}

\section{Neutral Detergent Fiber analysis and Acid Detergent Fiber (NDF, ADF)}

In Figure 4a, comparing the observed treatment RG-TR with and without bacteria, NDF \% being slightly higher in the treatment with bacteria $(35.66 \%)$. In the $\mathrm{A}-\mathrm{V}$ is the FDN\% range between $41 \%$ and $41.99 \%$, determining that silage has a better impact in the present investigation and his results coinciding with the work of Calsamiglia et al., 2004, who mention that the excellent quality silage is in the range of $39.3 \%-45.8 \%$ NDF.

In the RM treatment ranged between $59.49 \%$ with consortium and $59.95 \%$ without consortium, which are similar to the value observed by Fuentes 2001, (57.73\% NDF). But in this case not there is no significant difference between the treatments.

The evaluation of forages for NDF digestibility is being conducted to aid prediction of total forage digestibility, and 
researchers have demonstrated that the lactating dairy cows will consume more dry matter (DM) and produce more milk when fed forages that have higher NDF digestibility (Hoffman, 2001).

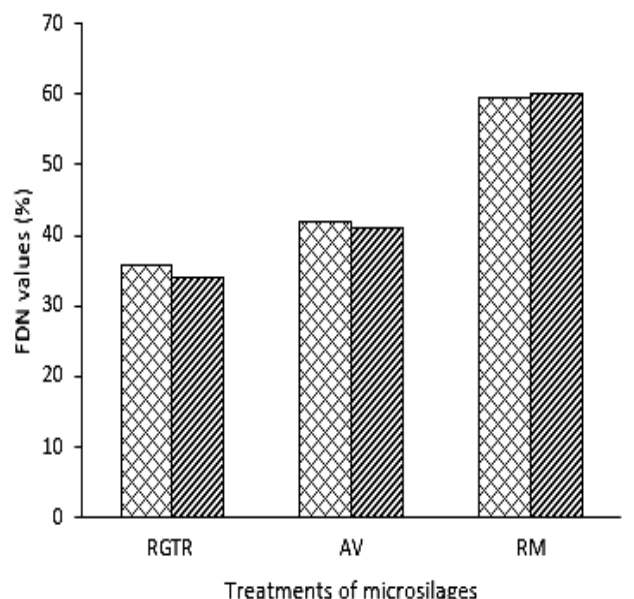

बconsortium

Without consortium

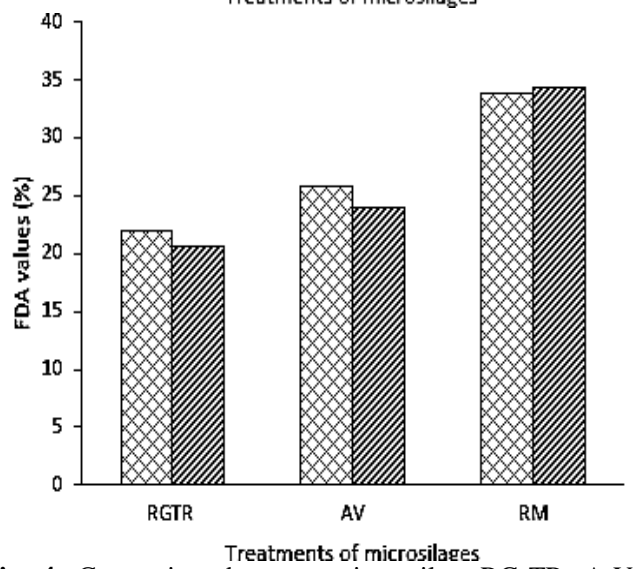

vconsortium

Zwithout consortium

Fig. 4: Comparison between micro silos: RG-TR, A-V, RM at 40 days of ensiling. a) \% NDF in the presence and absence of bacteria, b) \% ADF in the presence and absence of bacteria.

The Figure $1 \mathrm{~b}$ shows the results of ADF levels of bacterial and non-bacterial treatments. The RG-TR micro silo showed that the treatments with bacteria have a higher ADF level, with a value of $21.95 \%$, while treatments without bacteria had a lower ADF level (20.59\%). The AV micro silos treatments show that bacteria have a higher percentage of ADF $(25.85 \%)$ in comparison to the non-bacterial treatment $(24.02 \%)$. This value does not show any significant difference between treatments, but these values are lower than NDF values. ADF is used in many studies to define guidelines for high quality, as ADF increases, forage quality declines (Robinson et al., 1998). The results of RM micro silage showed that the highest ADF values (43.39\%) were displayed by the non-bacterial treatments, while treatments that held bacteria that reached to a $33.88 \%$ ADF value. These results are lower than those obtained by Fuentes (2001) $40.75 \%$ and $46.75 \%$.

\section{CONCLUSIONS}

On the basis of phenotypic characterization, bacterial population in RG-TR, A-V and RM treatments consisted of:
Lactobacillus buchneri, Lactobacillus plantarum, Lactobacillus brevis and Pediococcus acidilactici. These three treatments with bacterias played an important role in the fermentation process by increasing the shelf life and enriching by degradation of macromolecules.

The inoculation of suitable acid lactic bacteria facilitated obtaining good nutritional quality silage with optimum values: Neutral detergent fiber (NDF), acid detergent fiber (FDA), crude protein (CP), ether extracts (EE), ash and energy.

The present research project compared the nutritional parameters and the digestibility in order to pinpoint that the treatments holding bacteria within turned out to be more efficient than the non-bacterial ones.

Microbial consortium is considered to be the most suitable strains for improving the quality of silages and thus is potential inoculants for silage production.

\section{ACKNOWLEDGMENTS}

The authors would like to gratefully acknowledge the Agro biotecnología Laboratorio, Universidad de las Fuerzas Armadas-ESPE and Instituto Nacional de Investigaciones Agropecuarias (INIAP) for providing all the necessary facilities throughout our research work. We also would like to acknowledge the contributions of our colleagues from different institutes for their constructive, helpful comments and suggestion in the preparation of this manuscript.

\section{REFERENCES}

Benson. Microbiological Applications Laboratory Manual in General Microbiology. Boston: McGraw Hill, 2001.

Cabeza, H. Enrique, Basics of Predictive Microbiology, University of Pamplona, Department of Microbiology, 2013.

Calsamiglia, A., A. Ferret and A. Bach. Nutritive value of forages and wet fibrous products. Foundation for the Development of Animal Nutrition, 2004; 70.

University, 2010

Cheeptham, N. Starch Agar Protocol. Thompson Rivers

Cobos, M. 2012. http://www.sagarpa.gob.mx. Retrieved on December 13, 2014.

Contreras, F., M. Marsalis and L. Lauriault. Microbial inoculants for silage: Its use in warm weather conditions. NM StateUniversity, C: 2009; 642.

Elferink, O., F. Driehuis, J. Gottschal and S. Spoelstra. The silage fermentation processes and their manipulation. Electronics Memories FAO Conference, 1999; 31-40.

Favre Miguel, L. Producir XXI, Producción animal y manejo de reservas, 2012.http://www.produccion-animal.com.ar/produccion.

Filya, I. The effect of Lactobacillus buchneri and Lactobacillusplantarum on the fermentation, aerobic stability, and ruminal degradability of low dry matter corn and sorghum silages. Journal of Dairy Science, 2003; 86(11): 3575-358.

Flores, $\mathrm{M}$ and M. Rodriguez, M. Animal Nutrition. Retrieved from University of Las Palmas de Gran Canaria, 2010.

Fuentes, J., C. Magaña, L. Suarez, R. Peña, S. Rodriguez and B. De la Rosa. Chemical analysis and in vitro restrojo corn (Zea mays) digestibility. Mesoamerican Agronomy, 2001; 12(2): 189-192.

Galyean, M. 1996. Laboratory Procedures in Animal Nutrition Research. Obtained fromTexas Tech University, Lubbock.

Guerrero, L. Jenny. 2013. bacterial communities in tropical forages and its relation to the quality and in vitro enzymatic digestibility in 
pigs, National Univesity of Colombia.

Gutierrez, L. 2009. Practical Assessment of silages and packaged henolajes. http://www.produccion-animal.com.ar/produccion_y _manejo_reservas/reservas_silos/129-evaluacion.pdf.

Hoffman. 2007. http://fyi.uwex.edu.

Lara, J. 2011. http://virtual library.dgb.umich.mx:8083.

Muck, R and L. Kung. Animal response to silage additives. In silage: Field to Feedbunk. Northeast Regional Agric, Engng Service, 1997; 187-189.

Nsereko, V., B. Smiley, W. Rutherford, A. Spielbauer, K. Forrester and G. Hettinger. Influence of inoculating forage with lactic acid bacterial strains that produce ferulate esterase on ensilage and ruminal degradation of fiber. . Animal Feed Science and Technology, 2008; 122 135 .

Pahlow, G., R. Muck, F. Driehuis and S. Oude Elferink. Microbiology of ensiling. Madison, WI: American Society of Agronomy, 2003; 31-93.

Quinn, M., M. May, N. DiLorenzo, D. Smith and M. Galyean. Effects of Distillers Grains and Substrate Steam-Flaked Corn
Concentration on In Vitro Dry Matter Disappearance, Gas Production Kinetics, and Hydrogen Sulfide Production. The Professional Animal Scientist, American Registry of Professional Animal Scientists, 2010; 26:365-374

Robinson, P., D. Putman and S. Mueller. Alfalfa and Forage. Alfalfa Work group, University of California, 1998; 1: 6-9.

Vieyra, M. A. 2006. http://www.vetzoo.umich.mx.

\section{How to cite this article:}

Roberto F, Diana C, Julio P, Rueda D, Johana Z, Diego R, Manjunatha B, Ravi M, Selvanayagam M. Identification and characterization of Lactobacillus bacterial genera most prevalent used to improve silage digestibility of important forage species for livestock sector. J App Pharm Sci, 2016; 6 (01): 035-041. 